\title{
PENGEMBANGAN KONTEN E-LEARNING PRAKARYA PADA ERA REVOLUSI INDUSTRI 4.0
}

\author{
Luh Putu Putrini Mahadewi ${ }^{1}$, I Made Tegeh ${ }^{2}$, Gusti Ayu Putu Pramitha Sari ${ }^{3}$ \\ 1,2,3 Program Studi Teknologi Pendidikan \\ Universitas Pendidikan Ganesha \\ Singaraja, Indonesia \\ e-mail: Ipp-mahadewi@undiksha.ac.id ${ }^{1}$, im- tegeh@undiksha.ac.id ${ }^{2}$, \\ Putu.Pramitha.Sari@undiksha.ac.id ${ }^{3}$
}

\begin{abstract}
Abstrak
Era Revolusi 4.0 memiliki dampak besar bagi perkembangan di berbagai sektor bidang di Indonesia, tak terkecuali di bidang pendidikan. hampir semua kegiatan pembelajaran dapat digunakan secara digital. Namun perkembangan ini masih kurang dimanfaatkan oleh guru. Masih banyaknya sarana dan prasarana yang tidak dimanfaatkan secara maksimal. Saat ini siswa di tuntut untuk lebih aktif dalam kegiatan pembelajaran. Penelitian ini dilatarbelakangi dari permasalahan belum tersedianya konten e-learning Prakarya untuk menunjang kegiatan pembelajaran. Penelitian ini bertujuan untuk (1) mengambarkan rancang bangun proses pengembangan konten e-learning (2) mendiskripsikan validitas hasil pengembanagn konten e-learning, (3) mengetahui efektivitas e-learning menggunakan schoology yang dikembangkan terhadap hasil belajar prakarya. Penelitian ini dilakukan di SMPN 2 Kerambitan dengan subjek penelitian berjumlah 28 orang. Teknik analisis data yang digunakan, yaitu analisis deskriptif kualitatif dan analisis deskriptif kuantitatif. Hasil penelitian (1) Pengembangan konten e-learning di era revolusi 4.0 dengan model pengembangan Hannafin and Peck meliputi tiga tahapan, yaitu (a) penilaian kebutuhan, (b) desain/perancangan, (c) pengembangan dan implementasi. (2) multimedia pembelajaran interaktif berorientasi pendidikan karakter valid dengan: (a) Hasil review ahli isi mata pelajaran menunjukkan konten e-learning berpredikat sangat baik $(90 \%)$, (b) Hasil review ahli desain pembelajaran menunjukkan konten e-learning berpredikat sangat baik (92,0\%), (c) Hasil review ahli media pembelajaran menunjukkan konten e-learning berpredikat sangat baik (96\%), (d) Hasil uji coba perorangan multimedia pembelajaran interaktif berorientasi pendidikan karakter berpredikat sangat baik $(92,2 \%)$, hasil uji coba kelompok kecil konten e-learning berpredikat sangat baik $(90,6 \%)$, dan hasil uji coba lapangan konten e-learning berpredikat sangat baik $(91,1 \%)$. 3) konten e-learning yang dikembangan efektif meningkatkan hasil belajar Prakarya.
\end{abstract}

Kata-kata kunci : Efektivitas, E-Learning, Pengembangan, Prakarya, Validitas

\begin{abstract}
The Era of Revolution 4.0 has a big impact on developments in various sectors in Indonesia, no exception in education. Almost all learning activities can be used digitally. But this development is still underutilized by teachers. There are many facilities and infrastructures that are not utilized maximally. While the students are currently in demand to be more active in learning activities. This research is backed by the problem of low utilization of infrastructure to support learning activities. This research aims to (1) describe the design of the development process for e-learning content (2) to describe the validity of the results of e-learning content, (3) Knowing the effectiveness of elearning using the schoology developed The results of the practice. The research was conducted in SMPN 2 Kerambitan with a research subject of 28 people. Data analysis techniques used, namely qualitative descriptive analysis and quantitative descriptive analysis. Results of the research (1) Development of the 4.0 Revolution e-Learning content with Hannafin and Peck development model includes three phases, namely (a) the need assessment, (b) design/designing, (c) development and implementation. (2) Interactive learning multimedia oriented educational character with: (a) The results of expert review of subjects showing the content of highly-qualified e-learning $(90 \%)$, (b) The results of review of learning design experts show content E-Learning is very well-
\end{abstract}


awarded (92.0\%), (c) The review of the learning media expert showed excellent elearning content $(96 \%)$, (d) Individual multimedia learning test results interactive educational characters oriented Very well- awarded $(92.2 \%)$, the small group test results of e-learning content are very well- awarded (90.6\%), and the e-Learning content field trial results are excellent $(91.1 \%)$. 3) e-learning content that is development effectively enhances the results Learn about Prakarya.

Keywords: Effectiveness, Development, E-Learning, Prakarya, Validity

\section{Pendahuluan}

Saat ini dunia sedang menghadapi era baru, yaitu Revolusi Industri 4.0. Era ini dihadapkan dengan sebuah fenomena disrupsi, yang berarti sebuah perubahan yang mendasar. Seiring dengan perkembang zaman, teknologi pun telah masuk ke dalam dunia pendidikan. Sekolah-sekolah saat ini sudah memfasilitasi dengan berbagai macam teknologi, seperti laboratorium computer. Ini menunjukkan bahwa dunia pendidikan juga tidak luput dari perubahan-perubahan akibat era revolusi 4.0. It is based on cooperation of industry and science and built on five pillars: (1) cutting edge technologies including additive manufacturing, virtual plant, loT, and augmented reality, (2) supporting the French companies, especially small to middle ones, to adapt to new technologies, (3) extensive employees' training, (4) strengthening international cooperation around industrial standards and (5) promotion of French industry of the future (Rojko, 2017). Pendidikan di Indonesia saat ini menggunakan kurikulum 2013 atau biasa disebut dengan K13 menjadi salah satu perkembangan dari era 4.0 dimana Kurikulum 2013 ini mempunyai tujuan menyeimbangkan softskill dan hardskill dari peserta didik. Prakarya merupakan salah satu mata pelajaran baru yang terdapat di kurikulum 2013 untuk anak Sekolah Menengah Pertama (SMP). Mata pelajaran ini merupakan Mata Pelajaran yang menggantikan Mata Pelajaran TIK dan Mulok. Prakarya adalah gabungan dari 4 mata pelajaran, yaitu (1) Kerajinan, (2) Budidaya, (3) Pengolahan dan (4) Rekayasa. Pada Mata Pelajaran ini peserta didik tidak hanya dituntut untuk membuat sebuah produk namun peserta didik juga diharuskan untuk mempelajari teori-teori yang terdapat dalam setiap pembuatan produk. Mata pelajaran ini juga mengajarkan tentang bagaimana berwirausaha sejak dini, ini merupakan salah satu konsep dari Revolusi Industri 4.0 tentang bagaimana manusia seharusnya berinovasi untuk mendapatkan pekerjaan.

Dalam bidang pendidikan diharapkan teknologi saat ini dapat mempermudah proses pembelajaran. Saat ini banyak dikembangakan proses pembelajaran jarak jauh menggunakan $E$ - Learning. menjelaskan e-learning merupakan pembelajaran berbasis web yang bisa diakses dari internet. Pendapat ini didukung oleh Kamarga surharyanto (17-21) mendefinisikan e-learning sebagai kegiatan,belajar yang disampaikan melalui perangkat elektronik komputer yang memperoleh bahan belajar yang sesuai dengan kebutuhannya. Menurut Mutia (2013) E-learning berasal dari perpadanan dua kata yakni "e" dan "learning". "e" merupakan singkatan dari electronic dan learning adalah pembelajaran. Jadi E-learning secara harfiah dapat diartikan sebagai pembelajaran yang menggunakan media elektronik, khususnya perangkat komputer. Menurut Kusmana (2011) e-learning atau pembelajaran melalui online adalah pembelajaran yang pelaksanaannya didukung oleh jasa teknologi seperti telepon, audio, videotape, transaksi satelit atau komputer. Menurut Ariani (2018) dalam mengembangkan e-Learning dibutuhkan pengembangan yang sistematik dimulai dengan inventarisasi dan analisis kondisi yang ada, peninjauan keilmuan, sejarah pengembangan desain yang sejenis dan karakteristik populasi sebelum dikembangkannya e-Learning. Menurut Chusna (2019) Pembelajaran E-Learning, fokus utamanya adalah siswa atau peserta didik, dimana siswa dituntut mandiri terhadap waktu tertentu dan bertanggung jawab dalam pelaksanaan pembelajarannya, dan "memaksa" siswa memainkan peranan yang lebih aktif dalam 
pembelajarannya. Ini sangat berbeda dengan pembelajaran yang konvesional, atau tradisional, yaitu guru dianggap sebagai sumber ilmu atau seseorang yang serba tahu dan ditugaskan untuk menyalurkan ilmu pengetahuan kepada peserta didik atau siswa.

Ada 3 fungsi pembelajaran elektronik terhadap kegiatan pembelajaran di kelas, yaitu sebagai tambahan (suplemen), pelengkap (komplemen), atau pengganti (Substitusi). Contohnya dari platform penerapan e-learning adalah e-learning berbasis Schoology. Schoology adalah platform pembelajaran online gratis berbasis cloud, Schoology adalah salah satu program yang memberikan penggunanya fasilitas $e$ learning tanpa bayaran.

Berdasarkan hasil observasi yang dilakukan peneliti pada tanggal 18 Maret 2019 di SMPN 2 Kerambitan, Tabanan pada mata pelajaran prakarya di kelas VII, Diperoleh informasi tentang keterbatasan permasalahan pada proses belajar mengajar. Keterbatasan itu diantaranya (1) guru mendapat kesulitan untuk mencapai tujuan pembelajaran, dikarenakan kurangnya waktu untuk pertemuan tatap muka di kelas (2) siswa sering kali lupa akan materi yang telah diberikan sebelumnya (3) tidak semua siswa konsentrasi di kelas. (4) laboratorium komputer hanya sebatas browsing dan menggunakan word (5) berdasarkan materi yang sudah dipelajari sebelumnya, siswa cepat bosan dan bercanda jika diberikan ceramah maupun tugas di kelas. Dari hasil analisis data tersebut, dapat ditarik suatu analisis dasar bahwa proses pembelajaran di SMPN 2 Kerambitan pada mata pelajaran Prakarya khususnya kelas VII kurang optimal. Hal ini dikarenakan kurangnya memanfaatkan sarana dan prasarana yang tersedia di sekolah. Seperti penggunaan laboratorium dengan akses jaringan internet yang seharusnya mampu mendukung kegiatan proses pembelajaran. Maka dari itu, diperlukan sebuah pengembangan media untuk meningkatkan minat dan hasil belajar siswa. Media yang akan dipilih harus disesuaikan dengan kondisi siswa, karakteristik materi ajar, dan fasilitas yang tersedia. Untuk mengatasi permasalahan tersebut, siswa memerlukan waktu tambahan untuk mempelajari materi yang diberikan oleh guru sehingga siswa mampu memahami materi secara optimal. Salah satu cara agar siswa dapat mempelajari materi yang diberikan oleh guru tanpa harus mengganggu jam pelajaran yang lain adalah siswa diberikan media yang fleksibel yang dapat dipelajari dimana pun siswa berada. Salah satu media yang cocok dan memenuhi kriteria tersebut adalah media pembelajaran e- learning. Media pembelajaran e-learning ini dapat membantu siswa untuk mengingat kembali materi sebelumnya hanya dengan mengakses internet di sekolah maupun diluar sekolah.

Berdasarkan paparan tersebut, maka dalam penelitian ini dicoba untuk mengembangkan Konten E-Learning untuk Mata Pelajaran Prakarya Di Era Revolusi 4.0 Di SMPN 2 Kerambitan Tahun Pelajaran 2018/2019. Sejalan dengan pemaran diatas rumusan masalah penelitian ini sebagai berikut: 1) Bagaimana gambaran rancang bangun proses pengembangan e-learning ini di SMPN 2 Kerambitan untuk mata pelajaran Prakarya, 2) Bagaimana validitas hasil pengembangan e-learning menurut review para ahli dan uji coba produk ?, 3) Bagaimana efektivitas e- learning dengan schoology dikembangkan terhadap hasil belajar mata pelajaran Prakarya pada siswa kelas VII di SMPN 2 Kerambitan? Berdasarkan rumusan masalah adapun tujuan yang ingin dicapai dari permasalahan ini yaitu: 1) Untuk menggambarkan rancang bangun proses pengembangan e-learning SMPN 2 Kerambitan untuk mata pelajaran Prakarya, 2) Untuk mendeskripsikan Validitas hasil pengembangan e-learning menurut review para ahli dan uji coba, 3) Untuk mengetahui efektivitas e-learning dengan Schoology yang dikembangkan terhadap hasil belajar mata pelajaran Prakarya pada siswa kelas VII di SMPN 2 Kerambitan. 


\section{Metode}

Dalam penelitian ini peneliti menggunakan model pengembangan Hannafin dan Peck.Pemilihan model pembelajaran ini didasari atas pertimbangan bahwa desain pembelajaran model Hannafin and Peck ini model yang terstruktur sistematik melibatkan evaluasi dan revisi pada setiap tahapnya.

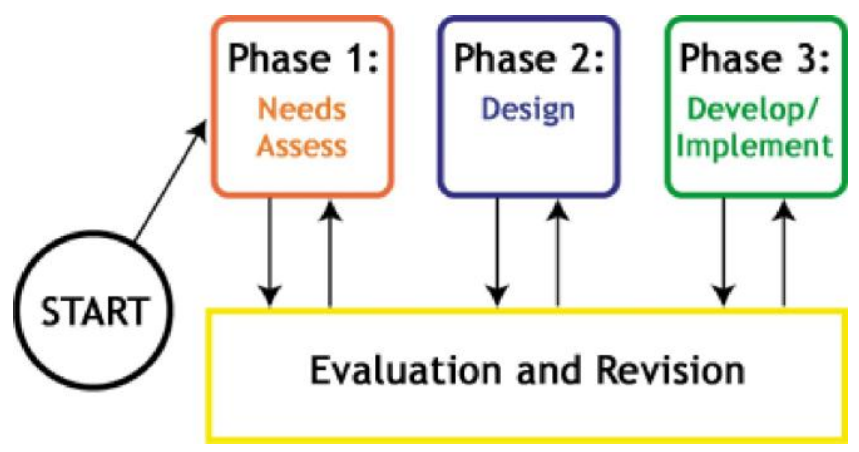

\section{Gambar 1. Model Pengembangan Hannafin and Peck}

Menurut Hannafin and Peck "model Hannafin and Peck terdiri atas tiga langkah, yaitu penilaian kebutuhan (need assessment), desain (pengembangan dan implementasi (development \& implementation), serta dalam setiap tahap melalui proses evaluasi dan revisi (Tegeh, dkk. 2014:2). Penelitian Pengembangan menggunakan tiga metode pengumpulan data untuk menjawab permasalahan mengenai proses pengembangan Konten e-learning, validitas Konten e-learning serta efektivitas Konten elearning yaitu, metode pencatatan dokumen, kuesioner/angket dan tes. Dalam penelitian pengembangan ini digunakan tiga teknik analisis data, yaitu teknik analisis deksriptif kualitatif, teknik analisis deskriptif kuantitatif, dan teknik analisis statistik inferensial (ujit).Sebelum melakukan uji hipotesis (uji-t berkorelasi) dilakukan uji prasyarat (uji normalitas dan homogenitas)..Uji normalitas dilakukan untuk mengetahui apakah sebaran skor pada setiap variabel berdistribusi normal atau tidak, untuk itu dapat digunakan rumus Liliefors.Adapun rumusnya sebagai berikut.

Menurut Koyan (2012: 108) adapun cara yang dapat dilakukan untuk menguji normalitas suatu data dengan teknik liliefors.Jika $\mathrm{L}_{0}<\mathrm{L}_{t}$, maka $\mathrm{H}_{0}$ diterima, sehingga dapat disimpulkan bahwa sampel berasal dari populasi yang berdistribusi normal.Uji homogenitas ini dilakukan untuk mencari tingkat kehomogenan secara dua pihak yang diambil dari kelompok- kelompok data terpisah dari satu sampel.Untuk menguji homogenitas varians data sampel digunakan uji Fisher $(F)$. Jika $F$ hitung $<F$ tabel, maka kedua kelompok data homogen. Sebaliknya, jika F hitung > F tabel, maka kedua kelompok data tidak homogen (heterogen) (Agung, 2015:76). Teknik analisis yang digunakan untuk pengujian hipotesis adalah teknik analisis uji-t.

\section{Hasil dan Pembahasan}

Tahapan awal dari model Hannafin dan Peck adalah Penilian kebutuhan, pada tahapan ini pengembang media pembelajaran akan menjelaskan kepada siapa produk ini akan ditujukan, lingkungan atau lokasi media atau produk akan digunakan, hambatanyang mungkin akan dihadapi, tujuan dan sasaran yang ingin dicapai. Fase kedua dari model hannafin and peck adalah fase desain. Tahap analisis kebutuhan ini dilakukan melalui wawancara dengan guru mata pelajaran Prakarya di SMPN 2 Kerambitan. Berdasarkan hasil wawancara diketahui bahwa permasalahan yang dihadapi selama proses 
pembelajaran yaitu guru lebih sering menggunakan metode ceramah daripada media pembelajaran kurang menarik, menjadikan siswa kurang tertarik untuk belajar sehingga menyebabkan Tujuan pembelajaran yang ingin dicapai tidak sesuai rencana dan nilai belajar siswa menjadi rendah. Pada tahap ini pengembang akan mengidentifikasi dan mengumpulkan alat-alat, bahan dan sumber yang digunakan. Dalam pengembangan atau mengimplementasikan Konten e-learning, pengembang dituntut untuk mengaplikasikan keterampilan yang dimiliki sehingga Konten e-learning dapat dikembangkan sesuai dengan desain yang telah dirancang. Pada tahap pengembangan atau implementasi pengembang media akan fokus melakukan aktivitas pengembangan membuat representasi grafis (flowchart). Tahap berikutnya yakni pada tahapan ini produk digunakan oleh pengguna. Uji Ahli Isi Mata Pelajaran. Produk multimedia pembelajaran interaktif dinilai oleh seorang ahli isi sekaligus sebagai guru mata pelajaran Prakarya di SMPN 2 Kerambitan atas nama Putu Yoga Sari, S,Pd. Menurut Mager dalam (Siswanto, 2008) Tujuan harus memuat atau mempunyai komponen $A, B, C$, dan D. jadi yang dimaksud dari $A, B, C$ dan D adalah Audience (Siswa), Behavior (tingkah laku yang diharapkan), Condition (kondisi), dan Degree (Derajat). Dalam menentukan materi guru harus mengidentifikasi jenis materi yang akan diajarkan, terdapat 5 jenis materi yaitu, 1) Fakta, 2) Konsep 3) Prosedur, 4) Prinsip, 5) Afektif. Kualifikasi sangat baik diperoleh karena jumlah soal dan umpan balik sudah sesuai dengan indikator dari materi yang disajikan.Ini sejalan dengan tujuan dari pengadaan evaluasi itu sendiri yaitu, untuk menentukan kualitas daripada sesuatu terutama yang berkenaan dengan nilai dan arti (Asrul, dkk, 2015). Berdasarkan hasil penilaian dari ahli isi mata pelajaran, setelah dikonversikan dengan tabel konversi persentasetingkat pencapaiannya sebesar $90 \%$ berada pada kualifikasi sangat baik.

Uji Ahli Desain Pembelajaran. Produk multimedia pembelajaran interaktif ini diujikan kepada seorang ahli desain pembelajaran atas nama Dewa Gede Agus Putra Prabawa, S.Pd.,M.Pd. metode yang digunakan dalam proses kegiatan e- learning dapat mengaktifkan siswa dalam proses belajar, berdiskusi dengan teman dan dapat diakses diluar jam pelajaran. sejalan dengan pendapat Suartama dkk, (2014:15) e-learning menjadi sangat populer dikarenakan fleksibilitas dan efektivitasnya. Melalui e-learning materi pembelajaran dapat diakses kapan saja dan dari mana saja. Berdasarkan hasil penilai dari ahli desain pembelajaran, setelah dikonversikan dengan tabel konversi persentase pencapaiannya sebesar $92,0 \%$ berada pada kualifikasi sangat baik. Uji Ahli Media Pembelajara ini diujikan kepada seorang ahli multimedia pembelajaran e-learning atas nama Adrianus I Wayan Ilia Yuda Sukmana, S.Kom.,M.Pd. Kemenarikan media juga dilihat dari dari gambar dan video yang disajikan dalam konten e-learning. Seorang pengembang konten e-learning sebaiknya selektif dalam memilih video ada baiknya jika pengembang menggunakan video berdurasi pendek dan isinya benar-benar menambah daya tarik materi pembelajaran, sehingga dapat meningkatkan motivasi belajar. (Suartama, dkk, $2014: 53$ ).

Berdasarkan hasil penilaian dari ahli media, setelah dikonversikan dengan tabel konversi, persentase tingkat pencapaiannya sebesar 96\%. Uji Coba Perorangan, Sebagai subjek dari uji coba perorangan ini adalah siswa kelas VII SMPN 2 Kerambitan berjumlah 3 (tiga) orang dengan hasil penilaian rerata persentase 92,2\%. Rerata persentase ini berada pada kualifikasi sangat baik. Uji Coba Kelompok Kecil berjumlah 9 (sembilan) orang dengan hasil penilaian rerata persentase $90,6 \%$. Rerata persentase ini berada pada kualifikasi sangat baik. Uji Coba Lapangan berjumlah 20 (dua puluh satu) orang dengan hasil penilaian rerata persentase $91,1 \%$. Rerata persentase ini beradapada kualifikasi sangat baik. Revisi pengembangan produk. Dalam pengembangan produk multimedia pembelajaran interaktif ini melalui enam tahapan yaitu (1) ahli isi mata pelajaran. (2) ahli media pembelajaran, (3) ahli desain pembelajaran, (4) uji coba perorangan, (5) uji coba kelompok kecil, (6) uji coba lapangan. Dalam ke enam tahapan revisi tersebut, ada sedikit revisi dan ada beberapa masukan serta saran dari para ahli dan subjek uji coba.

Berdasarkan nilai pretest dan posttest 21 orang siswa tersebut, maka dilakukan uji-t untuk sampel berkorelasi. Rata-rata nilai pretest adalah 61,1 dan rata-rata nilai 
posttest adalah 92,0. Peningkatan rata-rata nilai siswa ini juga dapat dilihat berdasarkan jawaban- jawaban siswa saat menjawab tes. Sebagian besar jawaban siswa yang salah saat pretest dalam menempuh posttest jawaban tersebut menjadi benar. Pada model Hannafin dan Peck proses evaluasi dan revisi berlangsung disetiap fase, sehingga ketiga fase dalam model ini terhubung pada tahap "mengevaluasi dan merevisi" (Tegeh, 2014: 1-5). Berdasarkan pemaparan hasil uji ahli dan efektivitas media dapat disimpulkan bahwa Konten e-learning ini efektif dalam membantu siswa dalam meningkatkan hasil belajar siswa pada mata pelajaran Prakarya tahun pelajaran 2018/2019. Ini dikarenakan Konten e-learning dapat menumbuhkan motivasi belajar siswa mengoptimalkan pemahaman siswa terhadap materi pembelajaran.

Tabel 1. Hasil Uji Validitas Produk

\begin{tabular}{|c|c|c|}
\hline $\begin{array}{c}\text { Subjek Uji Coba } \\
\text { Multimedia Interaktif }\end{array}$ & $\begin{array}{c}\text { Hasil } \\
\text { Validitas(\%) }\end{array}$ & Keterangan \\
\hline Ahli Isi Mata Pelajaran & 90,0 & Sangat Baik \\
\hline Ahli Desain Pembelajaran & 92,0 & Sangat Baik \\
\hline Ahli Media Pembelajaran & 96,2 & Sangat Baik \\
\hline Uji Coba Perorangan & 92,2 & Sangat Baik \\
\hline Uji Coba Kelompok Kecil & 90,6 & Sangat Baik \\
\hline Uji Coba Lapangan & 91,1 & Sangat Baik \\
\hline
\end{tabular}

(Sumber Data: Hasil Analisis Instrumen, 2019)

\section{Simpulan dan Saran}

Pengembangan Konten e-learning dilakukan melalui tahap analisis kebutuhan (need assesment), tahap desain (design), dan tahap pengembangan dan implemetasi (development and implementation). Hasil pengembangan Konten e-learning ahli isi mata pelajaran memperoleh persentase $90 \%$ dengan kategori sangat baik. Berdasarkan penilaian ahli desain pembelajaran, multimedia pembelajaran interaktif memperoleh persentase $92,0 \%$ dengan kategori sangat baik. Berdasarkan penilaian ahli media pembelajaran, multimedia pembelajaran interaktif memperoleh persentase $96 \%$ dengan kategori sangat baik. Persentase yang diperoleh dari uji coba perorangan yaitu $92,2 \%$ dengan kategori sangat baik. Persentase yang diperoleh dari uji coba kelompok kecil yaitu, 90,6\% dengan kategori sangat baik. Dan persentase yang diperoleh dari uji coba lapangan yaitu, 91,1\% dengan kategori sangat baik. Pengembangan Konten e-learning untuk mata pelajaran prakarya di Era Revolusi 4.0 yang dikembangan efektif meningkatkan hasil belajar Prakarya..

\section{Daftar Pustaka}

Agung, A.A. Gede. 2014. Metodologi Penelitian Pendidikan. Buku Ajar Metodologi Penelitian Pendidikan. Singaraja: Undiksha.

Ariani, Diana. 2018. Komponen Pengembangan E-Learning. Jurnal Pembelajaran Inovatif Vol. 1 No. 1 Hal. 58 - 65 .Tersedia Pada: http://journal.unj.ac.id/unj/index.php/jpi.

Chusna, Nuke L. 2019. Pembelajaran E-Learning. Prosiding Seminar Nasional Pendidikan KALUNI Volume 2 Hal. 113-117. Tersedia Pada: http://www.rumahpublikasi.com/index.php/prokaluni/article/download/36/20.

Koyan, I Wayan. 2012. Statistik Pendidikan “Teknik Analisis Data Kuantitatif”. Singaraja : Universitas Pendidikan Ganesha Press. 
Kusmana, Ade. 2011. E-Learning dalam Pembelajaran. Jurnal Ilmu Tarbiyah dan Keguruan Vol 14 No. 1 Hal. 35-51. Tersedia Pada: http://journal.uinalauddin.ac.id/index.php/lentera_pendidikan/article/view/3826/3495.

Mutia, Intan, Leonard. 2013. Kajian Penerapan E-Learning dalam Proses Pembelajaran di Perguruan Tinggi. Faktor Exacta Vol. 6 No. 4 Hal. 278-289. Tersedia Pada: https://journal.Ippmunindra.ac.id/index.php/Faktor_Exacta/article/download/239/225.

Sudarma, I Komang.dkk.2015.Desain Pesan. Yogyakarta: Graha Ilmu Suartama dan Tastra. 2014. E-Learning Berbasis MOODLE Yogyakarta: GRAHA ILMU.

Suharyanto. Adele B. L. Mailangkay. 2016. Penerapan E-Learning Sebagai Alat Bantu Mengajar Dalam Dunia Pendidikan. Volume 3 Nomor 417 Agustus - Desember 2016 Tersedia Pada Rojko. A. Industry 4.0 Concept: Background and Overview. Tersedia pada https://online-journals.org/index.php/i-jim/article/viewFile/7072/4532 diakses pada juli 2019

Tegeh, I Made dan I Made Kirna.2010. Metode Penelitian Pengembangan Pendidikan.Buku Ajar. Singaraja: Undiksha

Tegeh, I Made. dkk. 2014. Model Penelitian Pengembangan. Yogyakarta: GRAHA ILMU 